\title{
大脳基底核領域の脳血管断層撮影法
}

\author{
秋田県立脳血管研究センター放射線科 \\ 佐々木信夫・相、沢康夫・庄司安明 \\ （論文受付 昭和50年10月23日）
}

(Code No. 21322, 21435)

\section{ANGIOTOMOGRAPHY OF BASALGANGIONIC REGION}

\author{
By NoBUO SASAKI, \\ YASUO AIZAWA and \\ YASUAKI SHOJI \\ Division of Radiology, Research Institute \\ of Brain and Blood Vessels, 6-10 Senshu- \\ Kubota machi, Akita City, Akita.
}

(Article received; Oct. 23, 1975)

\section{Summary}

Technical studies of angiotomography for good demonstration of the vessels in the basal ganglia were described using a Princeps 50 unit.

From analyses of image quality and blurring effect of interfering shadows in multilayer tomography, the following technical factors were obtained for good demonstration of the vessels: five simultaneous cuts at $2 \mathrm{~mm}$ interval and swing angle of $30 \sim 40$ degrees in lateral projection, and five simultaneous cuts at 5 or $10 \mathrm{~mm}$ interval and swing angle of $10 \sim 20$ degrees in frontal projection.

Combination with photographic subtraction was particularly useful for good visualization of intracerebral avascular area.

\section{1.はじめに}

Rocca, Rosadini ${ }^{122}$ によって, 初めで行われた断層 撮影の脳血管造影への応用は，その後対象疾患，目的部 位を変えて試みられ，最近その診断価値が注目され，そ の有用性が強調されている3)ー5).

私よ゙もは Princeps 50 (CGR 社) を用いて脳血管断 層撮影を試み，検査方法や技術的問題，後頭蒀筒を中心 とした臨床応用の実例等を報告してきた。

本稿では，脳卒中の揨断上重要な基底核領域を支配す る。細くて特有の走向を示す線条体レンズ核動脈 (lenti- culostriate artery) 対象亡した. 具体的撮影条件と 2 , 3 の法を検討したので報告する.

\section{2. 線条体レンズ核動脈の $\mathrm{X}$ 線解剖像}

Fig. 1 は正常な線条体レンズ核動脈の正面像を昖大撮 影したものである・との動脈は中大脳動脈の主幹から分 岐後, 血流の方向と板反対に向かって僅かの距離を走っ た後, 再び外方に山な曲線を描きながら走る97。 その太 さは 0.2 0.8 mm であり, 正面像では正中面より約 $2.5 \mathrm{~cm}$ 離れ, 幅 $1 \mathrm{~cm}$ 位の内に存在する。通常血管撮 影で㫕出し得る本数は $3 \sim 6$ 本である. 
側面像は，普通の脳血管撮影（Fig. 2 a) では中大脳 動脈の分枝 insular segment と重なって蘵別が困難であ る. Fig. 2 b は中大脳動脈閉塞例である.中大脳動脈の

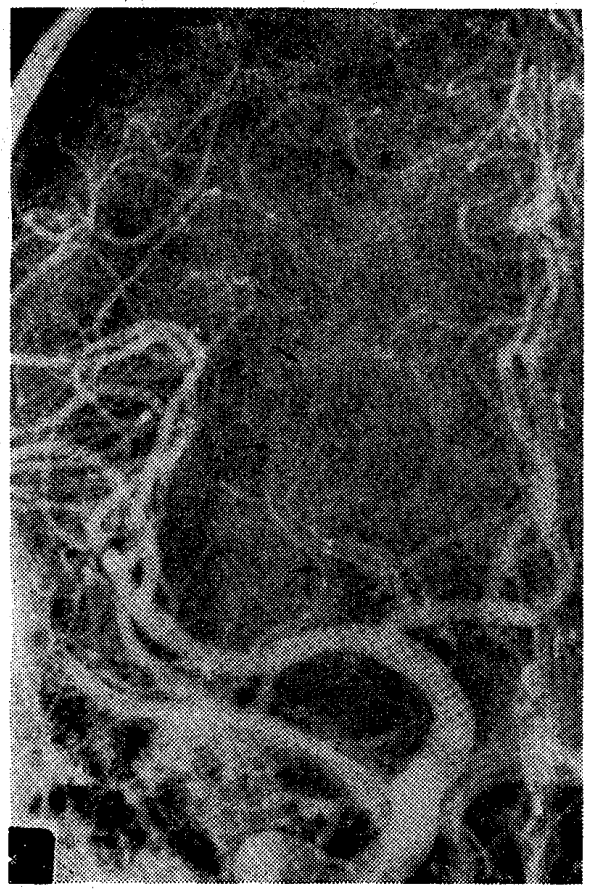

Fig. 1. 桩大撮影で捕えた線条体レンズ 核動脈の正面像

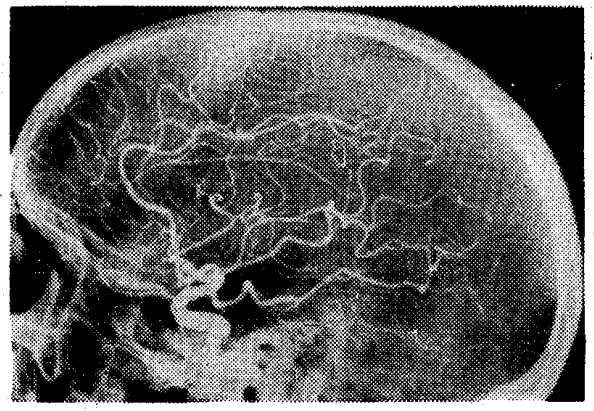

(a)

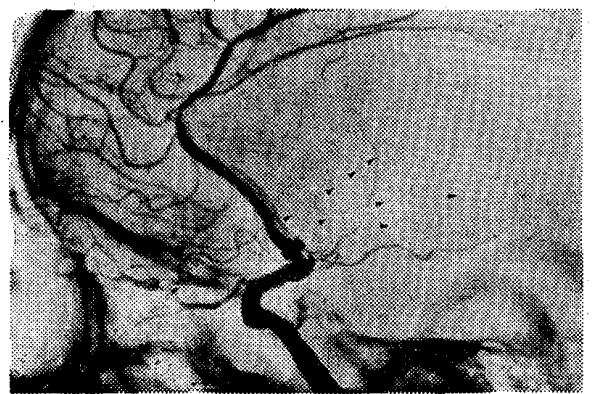

(b)

Fig. 2.（a ）正常頸動脈撮影の側面像.

(b) 中大脳動脈閉塞症. 中大脳動脈 が消去されると線条体レンズ核 動脈は良くみえる。 insular segment が消去されると，主幹加ら分忮後，䨒 形状に分散して走っているのが浔められる。

\section{3. 側面断層撮影の条件}

\section{1 カセッテの選定}

造影剤使用量の娍量, 同じ位相の多读锶察分析, 被嶨 線量の低娍の上から阔時多層撮影が望ましい。私よ゙もは 線条体レンズ核動脈が幅約 $1 \mathrm{~cm}$ の間にあるととを調べ， $2 \mathrm{~mm}$ 間隔 5 畨カセッテを使用した。

\section{2 振子角度}

$2 \mathrm{~mm}$ 間隔 5 閻カセッテを用いて，側面断層摄影する 時，情漧輩を鼠大にする振子角度をテストチャ一ト（フ ンク社製，Nr 7675，7980）を用して検副した。

测定は，テストチャートを断層照集面に圆定して撮影 を䘕い，つぎにテストチャートを照準泊から炏第に遠ざ けて撮影し，それぞれの振子所度及び照準面からの䟚離 について，識別できなくなるテストチャート像の大きさ

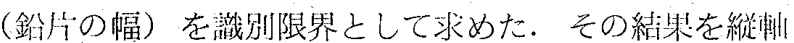
亿識别限界をとり，横軸には照準面汃らの距離をとりそ れぞれの振子角度について表わしたのが Fig. 3 である。

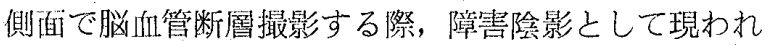
てくる中大脳動脈の insular segment の太さは $2 \mathrm{~mm}$ 前 後である，正常では線条体レンズ核動脈の外側枝之約 5 $\mathrm{mm}$ 以上の間隔がある。この障害敛影を少なくするには Fig. 3 から推測できる様に30度以上の振子角度が必要亡 なる。

つぎに，振子角度の変化による断尿撮影の画賲を調べ

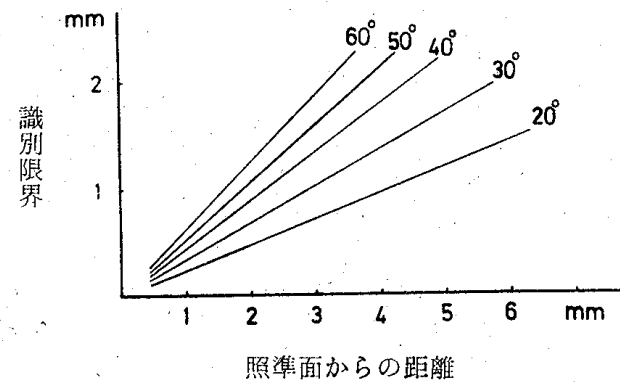

Fig. 3. 照準酒からの距離之識別限界との関係

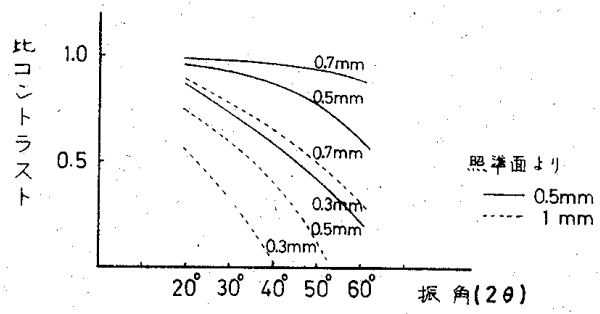

Fig. 4. 照準面より $0.5 \mathrm{~mm}$ 及び $1 \mathrm{~mm}$ 離れた ときの比コントラスト 
た。大宮等の報告 ${ }^{10}$ によれば，照準面からズレによる不 鋭は，照準面から，断層間隔の半分の距離 $(2 \mathrm{~mm}$ 間啊 では $1 \mathrm{~mm}$ ）の位犆だけズレた場合の不鋭は最大となり， さらにその半分，すなわち照準面から断層間霞の4 分の 1 の距離 $(0.5 \mathrm{~mm})$ だけズレた時の不釦をその平均値 としている．そこで私よ゙もは，テストチャートを断層照 準面より $0.5 \mathrm{~mm}$ 及び $1 \mathrm{~mm}$ 離して断廍撮影し, 单純撮 影に対する比コントラストを求めた。Fig. 4 はテストチ ヤートの鉛幅 $0.7 \mathrm{~mm}, 0.5 \mathrm{~mm}, 0.3 \mathrm{~mm}$ について表わ したあのである.40度以上の振子角度では照準面より 1 $\mathrm{mm}$ 離れた場合，蕾 $0.3 \mathrm{~mm}$ の像は識別不可能となる.

幅 $0.7 \mathrm{~mm}$ の像は $40 \%$ 以上のコントラスト低下が見られ

る。これから振子角度は40度が限度と考えた。

\section{3 時間的因子}

通常，脳血管撮影を行う時，第刺用の針はエラスタ針 $(19 \mathrm{G})$ を使用し, 造影剤注入器と針の連結はポリエチ レン管 (PE 260, 長さ $30 \mathrm{~cm}$ ) を用い, $8 \sim 10 \mathrm{cc}$ の造 影郕を 1 秒以内で注入している。乙の様な条件のむとで， 連続撮影されたX線写真から線条体レンズ核動脈が造影 されている時間を調べた結果約 2 秒であった。 Table. 1

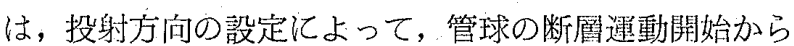
X線懪射開始までの時間（Lag time）乙振子角度によ って変わるX線曝射時間の変化を示した，線条体レンズ 核動脈を捕えるには，振子角度40度までが許容範閏とい える。

以上の事項より, 線条体レンズ核動脈を側面脳血管断

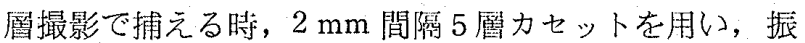
子角度 30 度〜 40 度で行う様にした。

\begin{tabular}{|c|c|c|c|c|c|c|c|}
\hline 管球位置 & 振子角度 & $10^{\circ}$ & $20^{\circ}$ & $30^{\circ}$ & $40^{\circ}$ & $50^{\circ}$ & $60^{\circ}$ \\
\hline 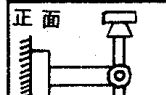 & Lag rime & $\begin{array}{l}1.4 \\
\mathrm{sec} \\
\end{array}$ & $\begin{array}{l}1.4 \\
\mathrm{sec} \\
\end{array}$ & $\begin{array}{l}1.4 \\
\mathrm{sec} \\
\end{array}$ & $\begin{array}{l}1.4 \\
\mathrm{sec} \\
\end{array}$ & $\begin{array}{l}1.4 \\
\mathrm{sec} \\
\end{array}$ & $\begin{array}{l}1.4 \\
\mathrm{sec} \\
\end{array}$ \\
\hline & 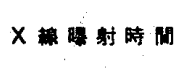 & 0.4 & 0.8 & 1.2 & 1.7 & 2.2 & 2.6 \\
\hline 制面 & Lag Time & 1.8 & 1.8 & 1.8 & 1.8 & 1.8 & 1.8 \\
\hline 量| & 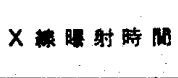 & 0.4 & 0.8 & 1.3 & 1.8 & 2.3 & 2.8 \\
\hline
\end{tabular}

Table 1. 振子角度之投射方向を変えた場合の Princeps-50 のもつ時間因子

\section{4. 正面断層撮影の条件}

前後像に抢いては線条体レンズ核動脈は，同時に造影 される後大脳動脈を除けば，他の血管像との重なりが少 ないといえる。しかし分布は前後倡いので，振子角度
は10度〜20度として厚い層を撮影するのが良いと考えた。 カセッテは $5 \mathrm{~mm} \sim 10 \mathrm{~mm}$ 間隔の多屓カセッテか，一般 撮影用カセッテで1枚撮りをするのが妥当と考えてい 万.

\section{5. 撮影の実際}

\section{1 撮影タイミングの適正化}

普通に遭続撮影を行い，乙れを基に脳血管断第撮影の 適応とするか不かを決め，どの位相帶の撮影が誩断上の 役に立つかを推定する，目標位相が決まったら撮影時間 と合致するように，造影剤注入器（CISAL-I）のタイマ 一を調節する

\section{2 断層面の設定}

侧泊断闎撮影を施行するときは，脳血管撮影の正面像 で，線条体レンズ核動脈柬の中心から正中面までの距離 を測定する。それをX線写真の拡大率で補让して，真の 中心断面を求めて撮影の照隻を行う。

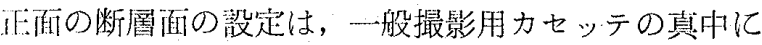
鉛線を付けてX線の中心線に合わせた状態で，紧純撮影 を行う。その写真を Fig. 5 の如く，脳血管撮影に董秝

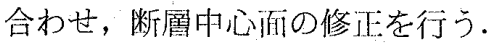

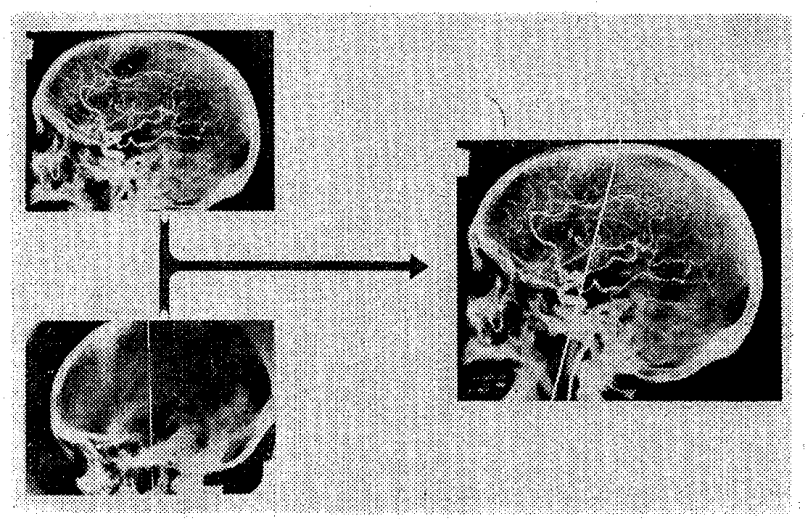

Fig. 5. 正面断尿時の中心断面の求め斻

\section{3 撮影条件}

问时多層撮影用増感紙に STE-5-2 形（桠光 $85 \mathrm{kVp}$ ) を用い，振子角度 30 度 40 度で䀧射時間は $1.3 \sim 1.4$ 秒と なるので，線条体レンズ㤥動脈の側面断贋を目的とする と, 焦点, フィルム間距離 $100 \mathrm{~cm}$ 前後で, $60 \mathrm{kVp} \sim 70$ $\mathrm{kVp}, 100 \mathrm{~mA}$ がほぼ標準である。

\section{6. 臨床的応用}

私どもが現任行っている，線条体レンズ核動脈の断層 造影例とそれに付髄した撮影処理法をあげてみたい。

6.1 症例 


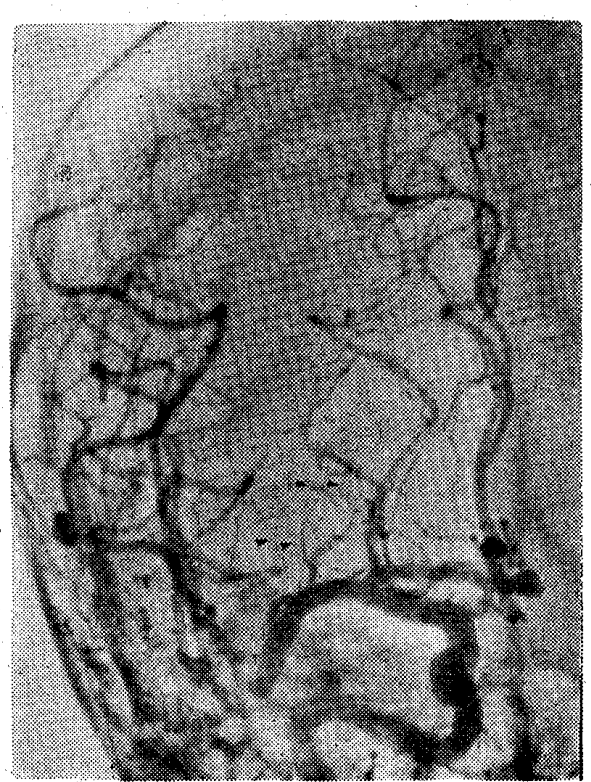

(a)

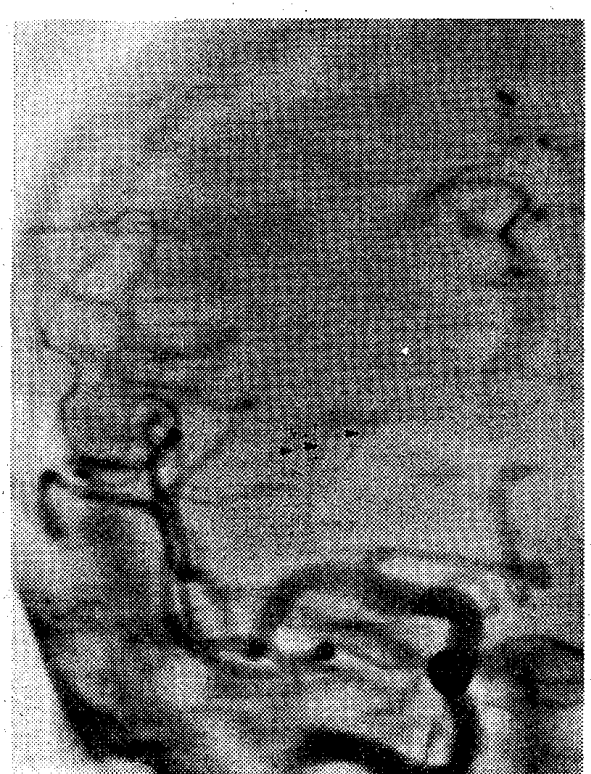

(b)

Fig. 6.（a ）脳出血例. 普通の脳血管撮影像 (b) 脳血管断首撮影像

Fig. 6 は脳出血例の正面像である.普通の脳血管撮影 (Fig. 6 a) では，線条体レンズ核動脈が後大脳動脈など と重なって見分けにくくなっている。脳血管断層撮影 （Fig. 6 b) 飞抢いては, 後大脳動脤が消去され線条体 レンズ核動脈の内側偏位が明らかである。

Fig. 7 は普通の脳血管撮影の側面像である. 中大脳動 脈の insular segment と重なって, 線条体レンズ核動脈

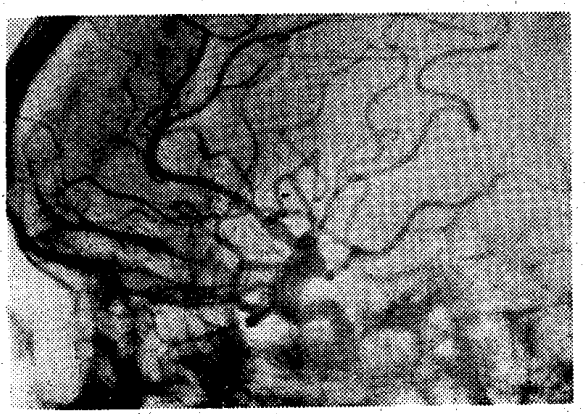

Fig. 7. 脳出血例での普通脳血管撮影像

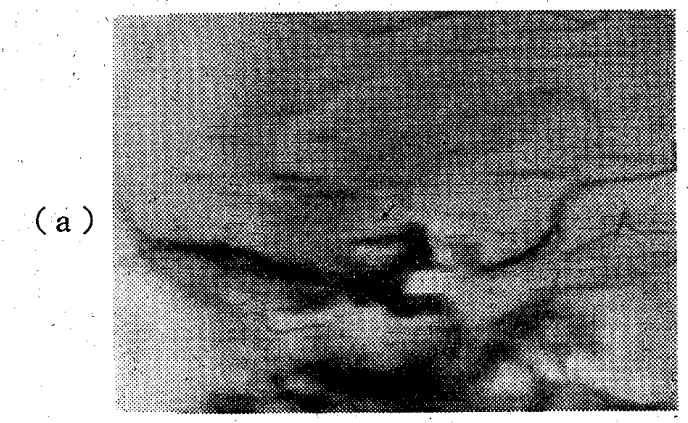

の走向を確認するととは困難で ある. Fig. 8 は $2 \mathrm{~mm}$ 間隔多層 断層撮影した 2 層目 (Fig. 8 a) と， 3 屬目(Fig. 8 b) である. 正中面之りの 2 層目では, 線条 体レンズ核動脈の内側枝の一部 がみられ，3層目では外側枝を 後下方に押し，内側枝を前へ生

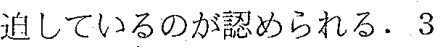
尿目では線条体レンズ核動脈を 血腫が前後に押し分けているの が明らかになり，血腫の拡がり の彰断㳇果をあげている。

\section{2 サブトララクションの}

\section{併用}

断㬝撮影はそれ自体サブトラ クション的役割を果たしている が，脳血管断廨撮影とサブトラ クションの併用を考え, 頭部の固定を十分にして予め学 純断層撮影をした上で, 頸動脈造影の中間相をねらって 断層撮影を行った，雨者の間でサブトラクションしたの が Fig. 9 で基底核域の血腫が無血管野として明瞭に描出 され，診断洒值を高めることができた。

\section{3 動・静脈相の同時観察}

動, 静脈相の相互関係を知るため, 乙れら两相の像を 1 枚の写真にとらえるととを試みだ．Fig. 10 a は動脈 相と静脈相が重なるような間隔で造影剤を 2 度注入し, 1 回の断層撮影で行ったものである. Fig. 10 b は動脈 相，静脈相をそれぞれ断層撮影し，静脈相を反転し重水 合わせたあのである.

これらの方法は, 動, 静脈相が 1 枚のフィルム上飞見 られることや，脳室の形の推定が同時にできる点で教育 的には意義があると思われる.しかし，いづれも手数が かかることなど問題点があり，写真自体もをれぞれの位 相を别々に撮影したものに比べ良いとはいえず苦学する

(b)

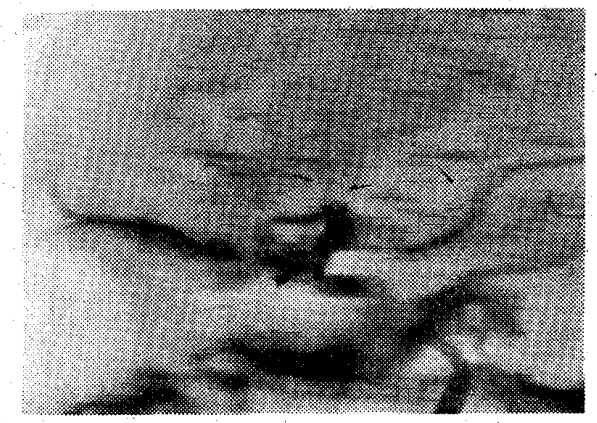

Fig. $8.2 \mathrm{~mm}$ 間隔 5 層カセッッテで撮影した脳血管断層の 2 層目 (a ) と 3 層目 


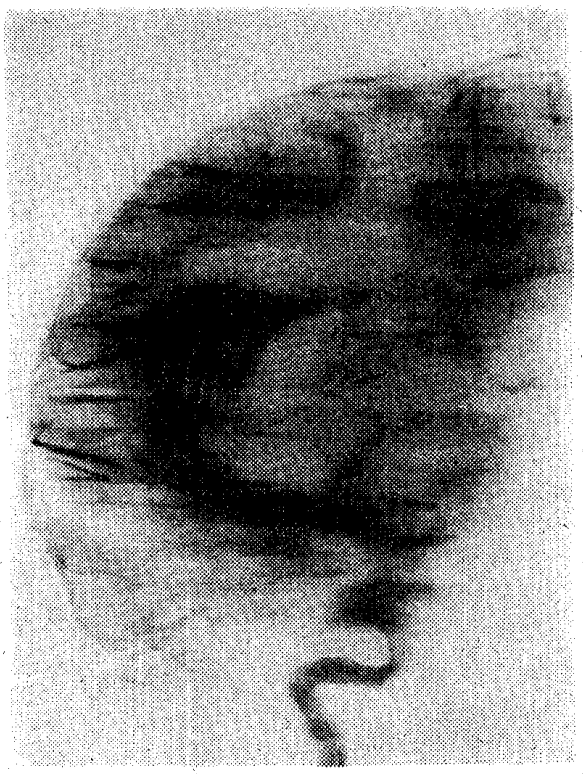

Fig. 9. 脸血管断層撮影で中間相を捕えた像に サブトラクションを併用した例

断層撮影に際して，断層面に一致した像をできるだけ 鮮鋭に写し出すと同時に，断層面から離れた像をできる だけ消去するには，必然的にX線の曝射角度を大とする 厅法が要求される。しかし線条体レンズ核動脈の像を目 的とした時, 振子角度が大き氙るととにより Fig. 4, Table. 1 の関係で情報量の低下がみられる.

私じむは目的とする線条体レンズ核動脈の側面断㬝撮 影に执いては，振于角度 30 度 40 度, 正面断層撮影では 10 度〜20度，乙の際のX線曝射時間は 2 秒以内加適当で あるという結論に達した。

また，多層撮影用増感紙を用いる時，管電圧などの調 節を行っても，第 1 㬝から第 5 㬝までのフィルム濃度の 均一性に火け検討の余地があるとはいえ，まず満足のい く写真が得られた。

脳血管断層撮影にサブトラクションを併用するととが， 讋断上有力になる場合がある，そのため患者の固定を十 分にして子予め単純断首撮影を行うように心がけている。

このことは断面位置, 撮影条件を確実にする意味です有 意義である。

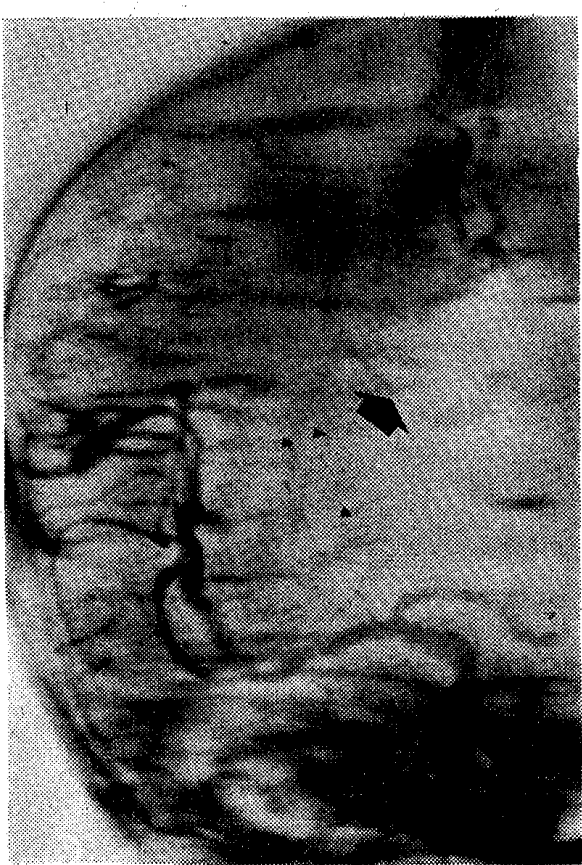

(a)

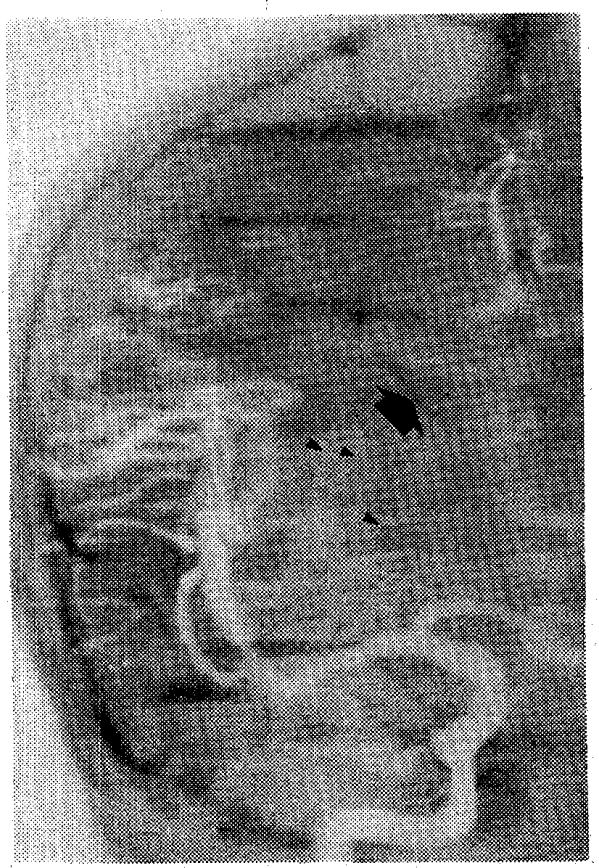

(b)

Fig. 10. 動, 静脈を 1 枚の写真に表わした例，（a ）は造影剂を 2 度注入し, 1 回の断層撮影を行った。（b）㭭々に撮影し静脈相を反転し重ね 合わせたものである。(印一静脈，、印一動脈）

割には効果が少なかった。

\section{8. おわりに}

線条体レンズ核動脈を目標之 した脳血管断層撮影法の撮影条 件を具体的飞検討し，その效果 を実例であげ，合わせてこの部 位の病変の描出を目的とした撮 影，写真上の処理の具体例を示 した（本報管の要旨は，第31回 日本放射線技術学会総会で発表 したあのである).

稿を終るにあたり, 終始, 御 指導, 御校閲を賜った前秋田県 立脳血管研究センター放射線医 学研究部長 (現, 山形大学教授) 山口昂一博士, 御教示, 御助言 をいただいた放射線医学研究部 長, 上村和夫博士, 同主任研究 員, 奥寺利男博士に媣く感謝の

\begin{abstract}
意を表します。
\end{abstract}

\section{文献}

1) Rocca, P. and Rosadini, G.: Cerebral Angiostratigraphy, First practical results.' Radiology, 77, 223-227, 1961 .

2) Rosadini, G. und Rocca, P.: Simulatane mersch- 
ichtige Tomographie und ihre Anwendung in der Gehirnangiographie. Acta radiol. Diag., 1, $385-388 ; 1963$.

3) Du Boulay, G. H. and Jackson, D. C.: Cranial angiotomography. Clin. Radiol. 16, 148-153, 1965.

4) 戸谷重雄，他：脳血管断尿等。脳之神経, 23,1439 $1445,1971$.

5）山二朗一，他：脳血管断層撮影法の技術的問題之嵒 休的応用. 臨休放射線, 19, 527-534, 1974.

6）生司安明，他：CGR 社製 Princeps-50 による脳血 管断層撮影，第30回日放技術学会総会抄録集，100，
1974.

7) 相沢康夫，他：神経放射線領域における検查技術 (脳血管撮影について). 第30回日放技術学会総会 抄録集，38-39，1974。

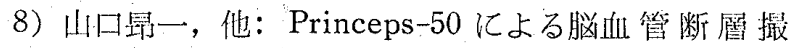
影. 断尿撮影会誌，2，1，109-111，1974。

9）原一夫, 他: 脳疾患のレ線彰断. p. 124, 䀢学書 院.

10）大宮健児，他：问時多層断穈の写真画質に及ぼす增 感紙の性能。第30回日放技術学会総会抄録集，174$175,1974$.

\section{MIX-DP. PHANTOM}

\begin{tabular}{|c|c|c|}
\hline 全 & 品 種 表 & (単位 $\mathrm{M} / \mathrm{M}$ ) \\
\hline 沙: 方 形 型 & $300 \times 300$ & $5,10,20,40,50,(80)$ \\
\hline 枌肞形 型 & $\begin{array}{l}300 \times 200 \\
300 \times 250\end{array}$ & $10,20,40,50, \quad(80)$ \\
\hline 川 形 型 & $\begin{array}{l}300 \phi \\
250 \phi\end{array}$ & \\
\hline 特 殊 型 & $\begin{array}{l}300 \times 400 \\
250 \times 250 \\
200 \times 200 \\
\end{array}$ & $5,10,20,40,50$ \\
\hline サイコ口型 & $\begin{array}{l}80 \phi, 120 \phi \\
140 \phi, 150 \phi\end{array}$ & \\
\hline 人体模造形型 & \multicolumn{2}{|c|}{$\begin{array}{l}\text { 頭荎部、胸部、腰部、( } \\
\text { 全姿 (座高型) }\end{array}$} \\
\hline
\end{tabular}

○枚数及び組合せは自由に選定下さい。

○線量計 (IONEX、ラドコン、TLD、ソ，他)

測定用穿孔加工も申し受けます。

(線量計種類、No.、図面、X 線フィルム等 提供下さ.い。)

○人体の場合 $\left\{\begin{array}{l}\text { 男……1 枚厚 } 30 \mathrm{M} / \mathrm{M} \\ \text { 女……1 枚厚 } 35 \mathrm{M} / \mathrm{M}\end{array}\right.$

○不良製品については即時取替え致します。

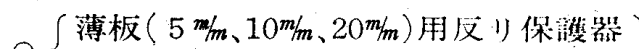

人体模造形（各部位）用反保㨦器 $\}$ 别注受け賜ります。

製造発宇元

\section{三和化成品株式会社}

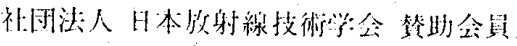

大阪市東区内本町橋詰丁 12 番地 1 号 幸福相互ビル

T E L (06) $941-3096$

OA. C 樹脂製(水槽、楕円槽ファントーム、その他)加工 製品、線量計測定用穿孔加工も致します。 